\title{
Dye-Sensitized Solar Cell-Based Photovoltaic Thermal for Ethanol Distillation: A Narrative Review
}

\author{
Aliefia Noor ${ }^{* 1)}$, Meri Hamdini' ${ }^{2)}$, Salsabila Ramadina ${ }^{3)}$, Yuant Tiandho ${ }^{4)}$ \\ Physics Department, University of Bangka Belitung \\ e-mail: ${ }^{* 1)}$ aliefianoor@gmail.com
}

\begin{abstract}
The potential for solar energy in Indonesia is abundant and attractive to be developed into one of the leading renewable energy sources. Photovoltaic or solar cells are devices that can be used to convert solar energy directly into electrical energy. A dye-sensitized solar cell (DSSC) is an exciting type of solar cell to be developed because it is cheap, easy, and can use natural dyes based on plant extracts. However, the performance of DSSC degrades when it is at high operating temperatures. In this article, a narrative review is presented to improve the efficiency of DSSC by integrating with a solar collector in the form of a photovoltaic/thermal (PV/T) system. The solar collector will act as a heat absorbent from the DSSC, and the heat energy obtained will be used to distill ethanol. Optimization in the ethanol distillation system can take advantage of $\mathrm{CuO}$ as a nanoparticle in the working fluid or better know as nanofluid.
\end{abstract}

Keywords: DSSC, ethanol, photovoltaic, photovoltaic thermal, solar collector. 


\title{
Fotovoltaik Termal Berbasis Dye-Sensitized Solar Cell untuk Distilasi Etanol: Sebuah Kajian Naratif
}

\author{
Aliefia Noor ${ }^{* 1)}$, Meri Hamdini ${ }^{2}$, Salsabila Ramadina ${ }^{3)}$, Yuant Tiandho ${ }^{4)}$ \\ Jurusan Fisika, Universitas Bangka Belitung
}

\begin{abstract}
Abstrak
Potensi energi surya di Indonesia melimpah dan menarik untuk dikembangkan menjadi salah satu sumber energi terbarukan. Fotovoltaik atau sel surya merupakan divais yang dapat digunakan untuk mengubah energi surya tersebut menjadi energi listrik secara langsung. Dye-sensitized solar cell (DSSC) merupakan salah satu jenis sel surya yang menarik untuk dikembangkan karena murah, mudah, serta dapat menggunakan $d y e$ alami berbasis ekstrak tanaman. Namun, DSSC mengalami degradasi performa ketika berada pada temperatur operasional yang tinggi. Di dalam artikel ini, diberikan suatu kajian guna memperbaiki efisiensi DSSC, yaitu melalui pengintegrasian dengan kolektor surya dalam bentuk sistem fotovoltaik/thermal (PV/T). Kolektor surya akan berperan sebagai absorben panas dari DSSC dan energi panas yang diperoleh akan digunakan untuk mendistilasi etanol. Pengoptimalan dalam sistem distilasi etanol dapat memanfaatkan $\mathrm{CuO}$ sebagai nanopartikel pada fluida kerja atau yang lebih dikenal dengan nanofuida.
\end{abstract}

Kata kunci: DSSC, etanol, fotovoltaik, kolektor surya, photovoltaic thermal.

\section{Pendahuluan}

Sebagai negara yang terletak di daerah tropis, potensi sumber energi matahari di Indonesia menarik untuk dimanfaatkan. Hal ini dikarenakan potensi energi surya pada mayoritas wilayah di Indonesia adalah sekitar $4,5 \mathrm{kWh} / \mathrm{m}^{2}$ perhari (Widodo \& Andrasto, 2010; Rumbayan et al., 2012; Handayani \& Ariyanti, 2012; Tiandho, et al., 2019). Sel surya atau fotovoltaik adalah suatu divais yang dapat digunakan untuk mengubah energi matahari menjadi energi listrik secara langsung (Santoso \& Puspitasari, 2018). Saat ini, terdapat beberapa jenis sel surya yang telah dikembangkan seperti: sel surya berbasis silikon sel surya organik, dye-sensitized solar cell (DSSC), dan sel surya perovskite. Perbedaan utama dari beberapa jenis sel surya tersebut terletak pada tipe material yang digunakan dalam fabrikasi sel surya (Nayak $e t$ al., 2019; Byranvand et al., 2018).

Meskipun DSSC merupakan jenis sel surya yang saat ini efisiensinya berada di bawah sel surya silikon, namun DSSC mampu memberikan potensi pengembangan sel surya yang murah dan ramah lingkungan (Susmiyanto et al., 2013; Hug et al., 2013). Bahkan DSSC dapat menggunakan ekstrak yang berasal dari berbagai tanaman sebagai dye alami. Beberapa ekstrak tanaman yang telah dimanfaatkan diantaranya adalah karamunting (Santoso \& Puspitasari, 2018), manggis, (Agustini, 2013), dan pandan (Dahlan et al., 2016), dan rosella (Andari, 2017).

Tetapi seperti kebanyakan sel surya, performa DSSC juga dipengaruhi oleh temperatur operasional. Semakin tinggi temperatur operasional, maka semakin rendah efisiensi dari DSSC (Belarbi et al., 2014). Padahal di sisi lain, sel surya umumnya dioperasikan di bawah sinar matahari langsung agar memperoleh penyinaran matahari secara optimal.

Solusi yang dikembangkan saat ini untuk mengatasi permasalahan degradasi efisiensi sel surya adalah mengintegrasikan sel surya dengan sistem kolektor surya (Jia et al., 2019; Joshi \& Dhoble, 2018). Berbeda dengan sel surya yang memanfaatkan energi cahaya matahari, kolektor surya bekerja berdasarkan pemanfaatan energi panas matahari (Bhowmik \& Amin, 2017). Dalam tataran aplikasi, kolektor surya telah dikembangkan sebagai peralatan pemanas air (Abokersh et al., 2017; Jafar \& Sivaraman, 2017) dan memungkinkan untuk dimanfaatkan dalam sistem distilasi alcohol (Weldekidan et al., 2018; Nuriana \& Triono, 2019). Oleh karena itu peng- 
integrasian sel surya khususnya DSSC dengan kolektor surya diharapkan dapat membantu DSSC menurunkan temperatur operasional dan di sisi lain, panas yang diterima dapat dimanfaatkan pada sistem pemanas. Adapun sistem terintegrasi tersebut lazim disebut dengan photovoltaic/thermal (PV/T) (Sultan \& Efzan, 2018).

Komponen PV/T yang berperan penting dalam proses penyerapan ataupun pemindahan energi panas adalah fluida kerja. Fluida kerja difungsikan sebagai aliran untuk memindahkan panas yang diserap. Selain air dan nanofluida, salah satu fluida kerja yang dapat dimanfaatkan adalah etanol. Penggunaan etanol, dalam hal ini adalah etanol tidak murni misal bio-etanol yang baru dipanen, memiliki dua manfaat sekaligus yaitu sebagai media transfer panas untuk PV/T dan sekaligus juga dapat dimanfaatkan untuk proses pemurnian (distilasi) etanol itu sendiri (Rianda, 2017; Huide et al., 2017).

Melalui artikel ilmiah ini, disajikan suatu kajian naratif terkait potensi pengembangan PV/T berbasis DSSC untuk distilasi etanol. Diharapkan melalui kajian naratif ini diperoleh gambaran yang lebih komprehensif terkait potensi pengembangan $\mathrm{PV} / \mathrm{T}$ berbasis DSSC mengingat mayoraitas $\mathrm{PV} / \mathrm{T}$ saat ini menggunakan sel surya silikon. Adapun penerapannya pada sistem distilasi etanol merupakan upaya agar teknologi ramah lingkungan yang dikembangkan memiliki dampak yang lebih luas dari segi pengaplikasiannya.

\section{Metode Penelitian}

Metode yang digunakan dalam penulisan artikel ini adalah narrative review, yaitu sebuah kajian berdasarkan literatur baik literatur nasional maupun internasional melalui google scholar. Kata kunci yang digunakan pada tahap awal adalah "DSSC", "Dye alami", "Photovoltaic", dan "Distillation ethanol". Pencarian tahap awal didapat 46.600 hasil untuk DSSC; 8.930 hasil untuk dye alami; 1.200.000 hasil untuk photovoltaic; dan 591.000 hasil untuk distillation ethanol. Setelah itu dilakukan identifikasi dan merelevansikan jurnal dengan tujuan penulisan, sehingga sebanyak 45 jurnal yang digunakan.

\section{Hasil dan Pembahasan}

\section{Konsep Dasar Photovoltaic/Thermal (PV/T)}

Kolektor fotovoltaik hibrida atau yang lebih dikenal dengan PV/T adalah perangkat yang mengubah energi matahari menjadi listrik dan panas (Charalambous et al., 2007). $\mathrm{PV} / \mathrm{T}$ terdiri dari modul PV (photovoltaic) yang digabungkan dengan perangkat ekstraksi panas (kolektor surya) sehingga dapat menghasilkan listrik dan pemanfaatan energi panas secara bersamaan (Yazdanifard \& Ameri, 2018). Mayoritas, modul PV mengubah $4-17 \%$ dari energi surya yang masuk menjadi energi listrik dan lebih dari 50\% diubah menjadi panas (Chow, 2010). Peningkatan panas pada PV tersebut mengurangi efisiensi sel surya seperti ditunjukkan oleh Gambar 1. Penurunan efisiensi PV akibat peningkatan temperatur operasional berkaitan dengan adanya penurunan tegangan yang diproduksi oleh PV (Berginc et al., 2007; Boisandi, 2014; Suryana, 2016). Hal ini berkaitan dengan karakteristik intrinsik dari semikonduktor yang digunakan dalam PV (Tiandho et al., 2018). Padahal di sisi lain, PV membutuhkan penyinaran matahari yang optimal agar dapat membangkitkan energi listrik dengan baik. Oleh karena itu dibutuhkan suatu sistem pendingin yang dapat menjaga temperatur operasional PV (Gusa et al., 2019).

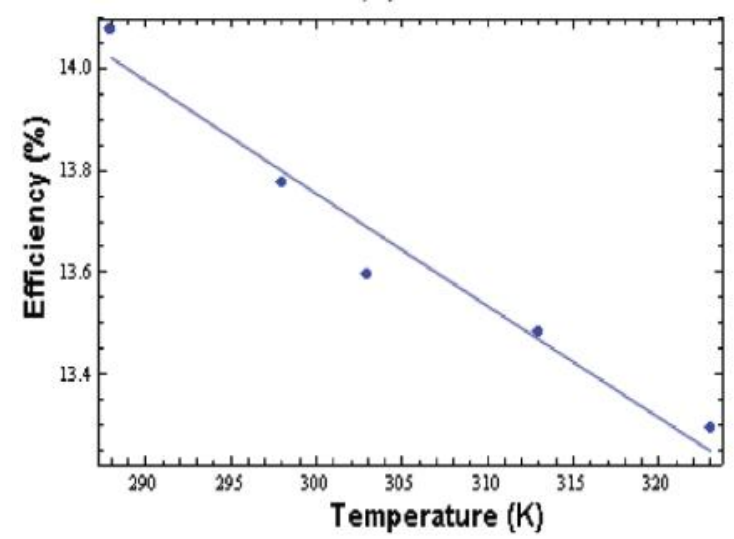

Gambar 1. Hubungan antara temperatur operasional dengan efisiensi sel surya (Tiandho, et al., 2018).

Perangkat kolektor surya yang terintegrasi dengan PV pada sistem PV/T akan membantu menyerap panas pada modul PV, 
sehingga PV mampu mempertahankan ataupun meningkatkan nilai efisiensi yang dihasilkan. Secara skematik, penampakan dari PV/T ditunjukkan oleh Gambar 2. Tampak bahwa pada dasarnya suatu sistem $\mathrm{PV} / \mathrm{T}$ tersusun dari modul PV yang dikontakkan dengan sistem penyerap panas yang menggunakan suatu fluida kerja, misal air, untuk proses transfer panas.

Secara ringkas, cara kerja dari $\mathrm{PV} / \mathrm{T}$ adalah sebagai berikut: energi radiasi matahari yang datang diserap oleh modul PV (He et al., 2006) yang kemudian diubah menjadi energi listrik dan panas. Ketika cahaya matahri mengenai plat absorber, sebagian cahaya dipantulkan lagi ke lingkungan dan sebagian besar diserap menjadi panas. Panas yang didapat kemudian dipindahkan atau dialirkan ke fluida yang bersirkulasi di dalam kolektor surya dan dapat dimanfaatkan dalam aplikasi seperti pemanas air (Samo et al., 2012).



(a)

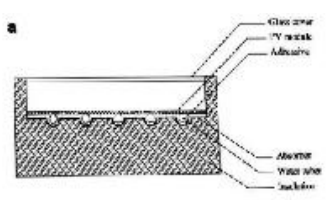

(b)
Gambar 2. (a) Bagian utam PV/T (Chow, 2010), (b) tampilan cross-section $\mathrm{PV} / \mathrm{T}$ (Charalambous et al., 2007).

Fluida yang digunakan pada sirkulasi alam kolektor surya dapat menggunakan udara ataupun cairan. Berdasarkan penelitian yang telah dilakukan efisiensi PV/T yang dihasilkan menggunakan cairan lebih besar dibanding menggunakan udara yakni; $22.6 \%$ menggunakan air, $21.01 \%$ menggunakan thermal oil, dan $18.49 \%$ menggunakan udara. Nilai efisiensi yang didapat dengan sistem hibrid baik menggunakan air, thermal oil ataupun udara sebagai fluida lebih tinggi jika dibandingkan PV tanpa sistem yakni, yang hanya mampu menghasilkan efisiensi rata-rata 10\% (Subarkah \& Belyamin, 2011).

\section{Photovoltaic Thermal (PV/T) untuk Distilasi Etanol}

Photovoltaic thermal merupakan suatu kombinasi sistem modul fotovoltaik dengan kolektor surya yang berada dalam satu alat/sistem. Penggunakan sistem hybrid, sel surya dapat mengubah radiasi sinar matahari menjadi energi listrik. Kombinasi dari kedua sistem ini akan menghasilkan energi listrik dan panas (van Helden et al., 2004).

Sebagian besar energi matahari yang diserap akan diubah menjadi panas. Hal ini mengakibatkan terjadinya kenaikan suhu kerja sel surya. Untuk mengatasi terjadi hal seperti kenaikan suhu kerja sel surya, maka diperlukan solusi untuk pendinginan modul fotovoltaik. Pendinginan modul fotovoltaik dapat dilakukan dengan menggunakan aliran fluida seperti udara air agar energi yang akan dihasilkan oleh modul fotovoltaik dapat ditingkatkan (Odeh \& Behnia, 2009).

Menurut (Chow, 2010), efisiensi termal sistem PV/T sekitar 9\% lebih rendah daripada kolektor termal surya konvensional. Oleh karena itu perkiraan rata-rata dari laminasi PV sangat sedikit mempengaruhi efisiensi termal. Perbedaan antara kedua sistem tersebut hanya sekitar 7\% dalam persentase cakupan beban pemanasan dan pendinginan dalam. Namun demikian, kinerja seperti persentase cakupan matahari sebenarnya dapat dipastikan bergantung pada letak geografis. Dalam waktu bersamaan, panas yang dihasilkan dapat digunakan untuk memanaskan air, memanaskan udara, dan lain-lain. Di dalam kajian ini, panas yang diterima digunakan untuk proses distilasi etanol. Distilasi merupakan proses pemisahan bahan cairan berdasarkan perbedaan titik didihnya. Berdasarkan pengertian distilasi, maka distilasi etanol berarti proses pemisahan antara alkohol dengan air atau proses ini biasanya disebut dengan proses untuk memurnikan etanol yang pada umumnya dilakukan dengan proses pemanasan menggunakan sumber energi (Duma \& Suanggana, 2018).

Secara sederhana pengembangan $\mathrm{PV} / \mathrm{T}$ untuk sistem distilasi etanol dapat dilakukan melalui modifikasi kolektor surya untuk keperluan yang sama seperti disajikan pada Gambar 3. Selain sistem penyerapan panas dan PV, sistem ini juga dilengkapi dengan kondensor yang berfungsi untuk mengubah uap etanol menjadi cair kembali (Neumann et al., 2017). Berdasarkan pengujian yang telah dilakukan diketahui bahwa sistem distilasi etanol menggunakan kolektor surya dapat mencapai temperatur $90^{\circ}$ dan proses distilasi 
dapat berjalan ketika temperatur dalam tanki penguap mencapai lebih dari $78^{\circ}$ (Walujo \& Harsanto, 2017; Duma \& Suanggana, 2018).

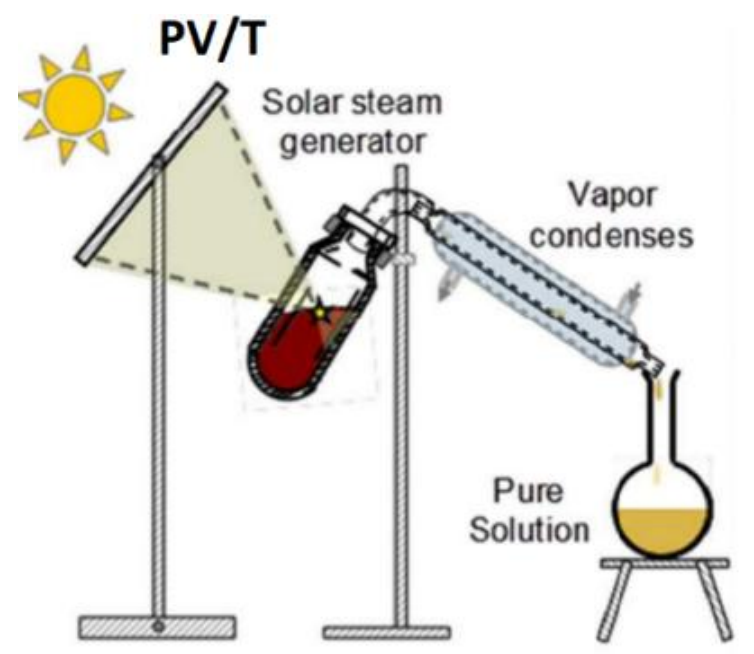

Gambar 3. Skema distilasi etanol dengan $\mathrm{PV} / \mathrm{T}$.

Prinsip pengembangan PV/T untuk sistem distilasi etanol dapat dilakukan melalui modifikasi kolektor surya untuk keperluan yang sama seperti disajikan pada Gambar 6 . Selain sistem penyerapan panas dan PV, sistem ini juga dilengkapi dengan kondensor yang berfungsi untuk mengubah uap etanol menjadi cair kembali (Neumann et al., 2017).

Berdasarkan studi yang pengkaji lakukan, pada bagian dalam kolektor surya akan diletakkan pipa-pipa tembaga yang didalamnya akan dialirkan fluida yaitu etanol yang menyebabkan temperaturnya akan mengalami kenaikan setelah melewati pipa tembaga (sisi keluar) akibat dari adanya penyerapan kalor yang berasal dari pancaran radiasi serta intensitas matahari dari sinar matahari yang tertangkap didalam kolektor surya. Fluida etanol disini digunakan sebagai sumber panas pada sistem photovoltaic untuk pemanasan air.

\section{Konsep Dasar Dye-Sensitized Solar Cell (DSSC)}

DSSC pada dasarnya merupakan sel surya generasi ketiga yang bekerja berdasarkan sistem fotoelektrokimia dengan proses pemisahan muatan terjadi pada semikonduktor sedangkan absorpsi cahaya dilakukan oleh zat pewarna. Secara sederhana, DSSC memiliki struktus seperti ditunjukkan oleh Gambar 4. Sel DSSC tersusun seperti suatu sandwich yang terdiri dari dua buah substrat konduktor transparan, seperti ITO, dengan bagian atas dilapisi oleh semikonduktor, biasanya $\mathrm{TiO}_{2}$ yang diberi dye. Adapun diantara kedua lapisan tersebut diisi dengan suatau elektrolit (Prasetyowati, 2012; Kumara \& Prajitno, 2012).

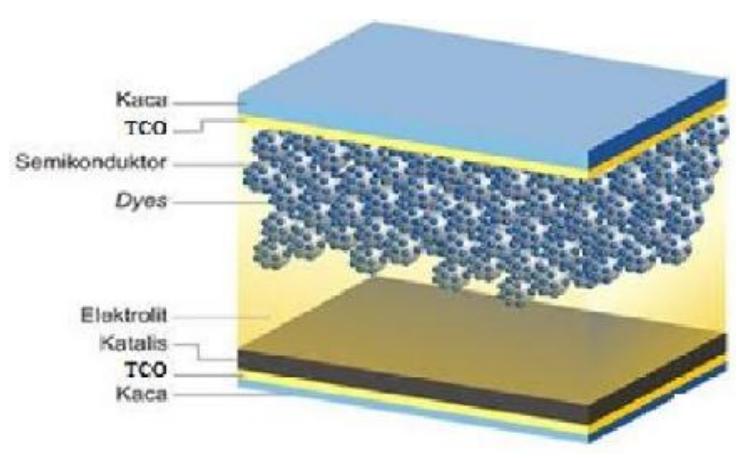

Gambar 4. Skema struktur DSSC (Indrajaya \& Poespawati, 2013).

Hal yang menarik dari pengembangan DSSC adalah tipe sel surya ini relatif mudah dan murah untuk dikembangkan. Selain kebutuhan $\mathrm{TiO}_{2}$, sumber utama performa DSSC terletak pada dye yang pada saat ini banyak dikembangkan dari ekstrak tanaman. Hal ini bertujuan agar sel surya yang dihasilkan bersifat ramah lingkungan dan tidak beracun. Pada Tabel 1 disajikan beberapa jenis dye alami yang berasal dari tanaman yang pernah digunakan pada fabrikasi DSSC.

Berdasarkan nilai efisiensi yang dihasilkan dari beberapa jenis dye alami, maka tanaman Rosella memiliki nilai efisiensi yang paling tinggi dan berpotensi untuk dikembangkan menjadi dye alami pada DSSC. 
Tabel 1. Beberapa jenis dye alami yang telah digunakan pada DSSC

\begin{tabular}{lcccl}
\hline \multicolumn{1}{c}{ Dye } & $\mathbf{V}_{\mathbf{o c}}$ & $\mathbf{I}_{\mathbf{s c}}$ & $\mathbf{n}(\boldsymbol{\%})$ & \multicolumn{1}{c}{ Ref. } \\
\hline Daun Karamunting & $0,46 \mathrm{~V}$ & $0.16 \mathrm{~mA} / \mathrm{cm}^{2}$ & 0.16 & (Santoso \& Puspitasari, 2018) \\
\hline Kulit Manggis & $358 \mathrm{mV}$ & $0.080 \mathrm{~mA} / \mathrm{cm}^{2}$ & 0.037 & \multirow{2}{*}{ (Agustini, 2013) } \\
Rhoeo Spatchacea & 294 & $0.019 \mathrm{~mA} / \mathrm{cm}^{2}$ & 0.013 & \\
\hline Pandan & $685 \mathrm{mV}$ & $18 \mu \mathrm{A}$ & 0.055 & \\
Black Rice & $610 \mathrm{mV}$ & $42 \mu \mathrm{A}$ & 0.053 & (Dahlan et al., 2016) \\
Akar kunyit & $598 \mathrm{mV}$ & $25 \mu \mathrm{A}$ & 0.056 & \\
\hline Rosella & $234 \mathrm{mV}$ & $0.3 \mathrm{~mA}$ & 0.52 & (Andari, 2017) \\
\hline Beras Ketan & $937 \mathrm{mV}$ & $468 \mu \mathrm{A}$ & 0.405 & (Hardeli, 2013) \\
\hline
\end{tabular}

Seperti umumnya sel surya, performa DSSC juga dipengaruhi oleh berbagai faktor lingkungan. Salah satu faktor yang paling mempengaruhi kinerja DSSC adalah temperatur operasional dan intensitas cahaya. Karena menggunakan semikonduktor pada proses generasi muatan maka sifat dasar DSSC juga identik dengan sifat semikonduktor yaitu nilai pita energinya dipengaruhi oleh temperatur. Pada Gambar 5 disajikan kurva I$\mathrm{V}$ DSSC untuk berbagai temperatur operasional.

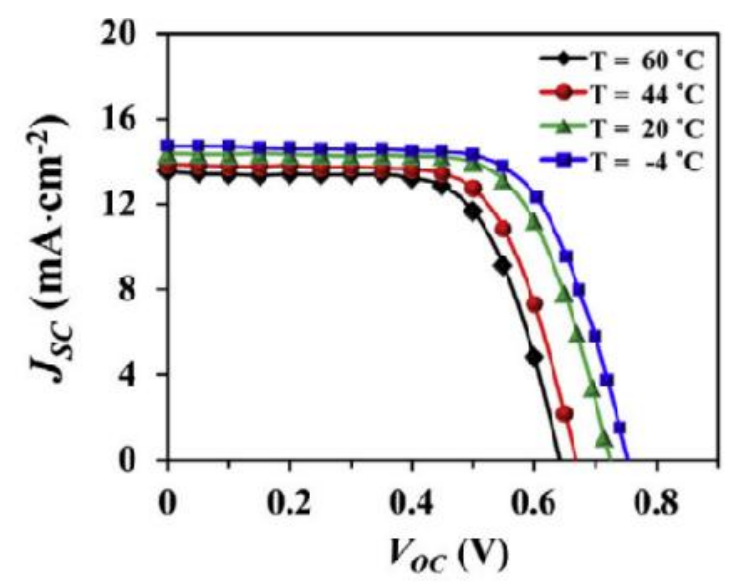

Gambar 5. Hubungan temperatur dengan kurva I-V DSSC (Kim et al., 2015)

Tampak bahwa semakin tinggi temperatur maka semakin rendah nilai rapat arus shortcircuti $\left(\mathrm{J}_{\mathrm{sc}}\right)$ dan tegangan open-circuit $\left(\mathrm{V}_{\mathrm{oc}}\right)$ yang digenerasi oleh DSSC (Kim et al., 2015). Oleh karena itu dibutuhkan suatu metode untuk dapat menjaga temperatur operasional DSSC agar stabil.

\section{PV/T Berbasis DSSC untuk Distilasi Etanol}

Fabrikasi PV/T berbasis DSSC untuk keperluan distilasi etanol dapat mengambil ide dasar dari pengembangan PV/T pada umumnya. Sistem PV/T dapat dibangun dengan mengkontakkan absorben panas yang diberi pipa-pipa tembaga berisi etanol belum murni dan dialirkan di bawah DSSC. Hal ini seperti ditunjukkan pada Gambar 6.

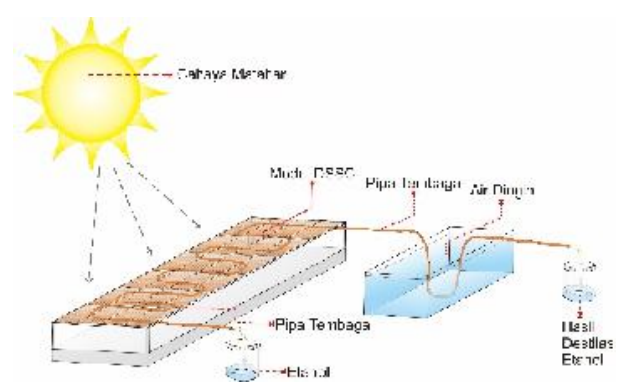

Gambar 6. Desain PV/T berbasis DSSC untuk distilasi etanol.

Permasalahan yang mungkin muncul pada sistem PV/T berbasis DSSC adalah rendahnya proses transfer panas dari ITO yang bersifat gelas ke absorben panas. Hal yang berbeda ketika PV yang digunakan adalah PV silikon yang umumnya dibagian bawahnya terlapisi oleh suatu logam. Perbaikan kinerja proses penyerapan panas pada PV/T berbasis DSSC dapat dilakukan dengan mendispersikan nanopartikel dengan konduktivitas termal tinggi seperti $\mathrm{CuO}$ ke dalam fluida kerja, dalam hal ini adalah etanol. Pendispersial nanopartikel $\mathrm{CuO}$ ke dalam fluida kerja 
nanofluida berbasis etanol yang memiliki konduktivitas termal yang baik pula. Dibandingkan dengan fluida dasarnya, yaitu etanol, nanofluida tersebut memiliki konduktivitas termal yang lebih tinggi.

Melalui penelitian yang dilakukan oleh (Noor, et al., 2020), diketahui bahwa penambahan nanopartikel $\mathrm{CuO}$ dalam suatu fluida (dalam hal ini adalah campuran etanol dan air) dapat mempercepat proses distilasi etanol. Berdasarkan Gambar 7 tampak bahwa nanofluida $\mathrm{CuO}$ dan air keduanya akan menuju nilai asimptotik berada di sekitar temperatur $85^{\circ} \mathrm{C}$. Namun, karena nanofluida $\mathrm{CuO}$ memiliki konduktivitas termal lebih baik maka proses penguapan etanol (distilasi etanol) lebih mudah terjadi. Hal ini dapat dibuktikan dari hasil etanol yang diperoleh dari kedua proses tersebut. Pada larutan yang berbasis etanol/air diperoleh etanol sebanyak $2.2 \mathrm{~mL}$, sedangkan pada etanol/nanofluida $\mathrm{CuO}$ dihasilkan etanol sebanyak $4 \mathrm{~mL}$. Berdasarkan hasil yang sudah diperoleh tersebut, dapat dilihat bahwa penggunaan nanofluida $\mathrm{CuO}$ dapat meningkatkan efektivitas distilasi etanol sebesar $81 \%$ (Noor et al., 2020).

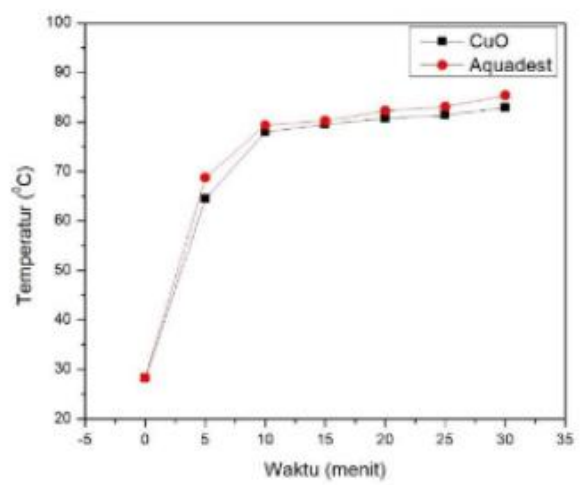

Gambar 7. Perbandingan hubungan antara waktu pemanasan dengan temperatur pada etanol/akuades dan etanol/nanofluida $\mathrm{CuO}$ (Noor et al., 2020).

Apabila PV dengan DSSC diintegrasikan melalui sistem PV/T distilasi etanol maka akan menghasilkan PV dengan efisiensi yang stabil karena temperaturnya yang terjaga. Hal ini dikarenakan pada saat PV mengalami kenaikan suhu kerja, integrasi dari PV/T akan bekerja untuk mendinginkan modul PV. Pengaplikasian PV/T berbasis DSSC juga dapat digunakan untuk proses distilasi etanol agar panas yang diterima dari modul PV tidak terbuang sia-sia.

\section{Kesimpulan}

Studi ini menyatakan bahwa perangkat $\mathrm{PV} / \mathrm{T}$ berbasis DSSC dengan dye alami dari ekstrak tanaman dapat meningkatkan kinerja dan efisiensi dari modul DSSC karena temperatur panel surya menjadi stabil. Selain itu, energi panas yang terkumpul pada $\mathrm{PV} / \mathrm{T}$ dapat digunakan dalam sistem distilasi etanol.

\section{Penghargaan}

Ucapan terimakasih disampaikan kepada Kementerian Pendidikan Nasional pada Program Kreativitas Mahasiswa tahun 2020.

\section{Daftar Pustaka}

Abokersh, M., El-Morsi, M., Sharaf, O. \& Abdelrahman, W. (2017). On-demand Operation of a Compact Solar Water Heater Based on U-pipe Evacuated Tube Solar Collector Combined with Phase Change Material. Solar Energy, 155, 1130-1147.

Agustini, S. (2013). Fabrikasi Dye Sensitized Solar Cell (DSSC) Berdasarkan Fraksi Volume $\mathrm{TiO}_{2}$ Anatase-Rutile dengan Garcinia mangostana dan Rhoeo Spathacea sebagai Dye Fotosensitizer. Jurnal Teknik ITS, 2(2), 131-136.

Andari, R. (2017). Sintesis dan Karakterisasi Dye Sensitized Solar Cells (DSSC) dengan Sensitizer Antosianin dari Bunga Rosella. JFA (Jurnal Fisika dan Aplikasinya), 13(2), 88-95.

Belarbi, M., Benyoucef, A., \& Benyoucef, B. (2014). Study of the Equivalent Circuit of a Dye-sensitized Solar Cells. Advanced Energy: An International Journal (AEIJ), 1(2), 1-8.

Berginc, M. U. O. K., Jankove, M., \& Topic, M. (2007). The Effect of Temperature on the Performance of Dye-sensitized Solar Cells Based on a Propyl-methylimidazolium Iodide Electrolyte. Solar Energy Materials \& Solar Cells, 91(9), 821-828. 
Bhowmik, H., \& Amin, R. (2017). Efficiency Improvement of Flat Plate Solar Collector Using Reflector. Energy Reports, 3, 119123.

Boisandi, A. (2014). Pengaruh Temperatur Anil Elektroda Grafit terhadap Karakteristik Arus dan Tegangan (IV) Dye Sensitizer Solar Cell (DSSC). Jurnal Pendidikan Informatika dan Sains, 3(1), 9-16.

Byranvand, M. M., Kim, T., Song, S., Kang, G., Ryu, S.U., \& Park, T. (2018). p Type $\mathrm{CuI}$ Islands on $\mathrm{TiO}_{2}$ Electron Transport Layer for a Highly Efficient Planar Perovskite Solar Cell with Negligible Hysteresis. Advanced Energy Materials, 8(5), 1702235.

Charalambous, P., Maidmen, G., Kalogirou, S., \& Yiakoumetti, K. (2007). Photovoltaic thermal (PV/T) collectors: A review. Applied Thermal Engineering, 27(2-3), 275-286.

Chow, T. (2010). A review on photovoltaic/thermal hybrid solar technology. Applied Energy, 87(2), 365379.

Dahlan, D., Leng, T. \& Aziz, H. (2016). Dye Sensitized Solar Cells (DSSC) dengan Sensitiser Dye Alami Daun Pandan, Akar Kunyit dan Biji Beras Merah (Black Rice). Jurnal Ilmu FIsika Universitas Andalas, 8(1), 1-8.

Duma, G., \& Suanggana, D. (2018). Distillation of Bioethanol From Nypa Using Flat Plate Solar Collector. Jurnal Teknik Mesin (JTM), 8(1), 1-4.

Gusa, R., Puriza, M., Tiandho, Y., \& Sunanda, W. (2019). Kinerja Panel Surya Apung pada Kulong Pasca Tambang Timah. Jurnal Nasional Teknik Elektro, 8(3), 136-141.

Handayani, N., \& Ariyanti, D. (2012). Potency of Solar Energy Applications in Indonesia. Int. Journal of Renewable Energy Development (IJRED), 1(2), 3338.

Hardeli, S. R. T. F. M. R. S. (2013). Dye Sensitized Solar Cells (DSSC) Berbasis Nanopartikel $\quad \mathrm{TiO}_{2} \quad$ Menggunakan Antosianin dari Berbagai Sumber Alami. Prosiding Semirata FMIPA Universitas Lampung, 155-161.

He, W., Chow, T.T., Ji, J., \& Lu, J. (2006). Hybrid Photovoltaic and Thermal Solar-
Collector Designed for Natural Circulation of Water. Applied Energy, 83(3), 199-210.

Hug, H., Bader, M., Mair, P., \& Glatzel, T. (2013). Biophotovoltaics: Natural Pigments in Dye-Sensitizer Solar Cells. Journal Applied Energy, 115, 216-225.

Huide, F., Xuxin, Z., Lei, M., \& Tao, Z. (2017). A Comparative Study on Three Types of Solar Utilization Technologies for Buildings: Photovoltaic, Solar Thermal and Hybrid Photovoltaic/ Thermal Systems. Energy Conversion and Management, 140, 1-13.

Indrajaya, Y., \& Poespawati, N. (2013). Unjuk Kerja DSSC Berbasis $\mathrm{TiO}_{2}$ dengan dye Ruthenium, Depok: Departemen Teknik Elektro, Fakultas Teknik, Universitas Indonesia.

Jafar, K., \& Sivaraman, B. (2017). Performance Characteristics of Parabolic Solar Collector Water Heater System Fitted with Nail Twisted Tapes Absorber. Journal of engineering science and technology, 12(3), 608-621.

Jia, Y., Guruprasad, A. \& Gulyin, F. (2019). Development and Applicaitons of Photovoltaic-Thermal Systems: A review. Renewable and Sustainable Energy Reviews, 102, 249-265.

Joshi, S., \& Dhoble, A. (2018). PhotovoltaicThermal Systems (PVT): Technology Review and Future Trends. Renewable and Sustainable Energy Reviews, 92, 848882.

Kim, J. H., Moon, K. J., Kim, J. M., \&, Lee, D. (2015). Effects of Various LightIntensity and Temperature Environments on the Photovoltaic Performance of dyeSensitized Solar Cells. Solar Energy, 113, 251-257.

Kumara, M., \& Prajitno, G. (2012). Studi awal Fabrikasi dye Sensitized Solar Cell (DSSC) dengan Menggunakan Ekstraksi Daun Bayam (Amaranthus Hybridus L.) sebagai dye Sensitizer dengan Variasi Jarak Sumber Cahaya pada DSSC. Jurnal Ilmiah ITS.

Nayak, P. K., Mahesh, S., Snaith, H., \& Cahen, D. (2019). Photovoltaic Solar Cell Technologies: Analysing the State of the Art. Nature Reviews Materials, 4(4), 269.

Neumann, O. et al. (2017). Combining Solar Steam Processing and Solar Distillation 
for Fully off-grid Production of Cellulosic Bioethanol. ACS Energy Letters, 2(1), 813.

Noor, A., Evi, J., Aisyah, D. A. T. S., Rifqi, A. R., \& Tiandho, Y. (2020). Synthesis of CuO-based Nanofluids Mediated by White Egg for Ethanol Distillation Applications. Stannum: Jurnal Sains dan Terapan Kimia, 2(1), 7-12.

Nuriana, W., \& Triono, J. (2019). Effect of Vacuum Level on Heating Speed on Ethanol Destillation Process Using Coaxial Vacuum Tube Solar Collector. IOP Conference Series: Materials Science and Engineering, 588, 012018.

Odeh, S., \& Behnia, M. (2009). Improving Photovoltaic Module Efficiency Using Water Cooling. Heat Transfer Engineering, 30(6), 499-505.

Prasetyowati, R. (2012). Sel Surya Berbasis Titania Sebagai Sumber Energi Listrik Alternatif. Proc. Seminar Nasional Penelitian, Pendidikan dan Penerapan MIPA, 1-6.

Rianda, R. (2017). Analisis Termal Kolektor Surya Tipe Plat Datar dengan Fluida Kerja Etanol 96\% pada Sistem Solar Water Heater. Jurnal Teknik Mesin Mercu Buana, 6(4), 244-251.

Rumbayan, M., Abudureyimu, A., \& Nagasaka, K. (2012). Mapping of Solar Energy Potential in Indonesia Using Artificial Neural Network and Geographical Information System. Renewable and Sustainable Energy Reviews, 16(3), 1437-1449.

Samo, S., Siyal, A., Siyal, Z., \& Rahman, A. (2012). Analysis of an Active and Passive Solar Water Heating System. International Water Technology Conference (IWTC), 16, 1-10.

Santoso, H., \& Puspitasari, N. (2018). Fabrikasi Dye Sensitizer Solar Cell (DSSC) Berbahan Dasar Ekstrak Daun Karamunting. Jurnal Borneo Saintek, 1(3), 63-67.

Subarkah, R., \& Belyamin. (2011). Pemanas Air Energi Surya dengan Sel Surya Sebagai Absorber. Poli-Teknologi, 10(3), 160871.

Sultan, S., \& Efzan, M. (2018). Review on Recent Photovoltaic/Thermal (PV/T)
Technology Advances and Applications. Solar Energy, 173, 939-954.

Suryana, D. (2016). Pengaruh Temperatur/ Suhu terhadap Tegangan yang Dihasilkan Panel Surya Jenis Monokristalin (Studi Kasus: Baristand Industri Surabaya). Jurnal Teknologi Proses dan Inovasi Industri, 1(2), 49-52.

Susmiyanto, D., Wibowo, N., \& Sutresno, A. (2013). Karakterisasi Ekstrak Antosianin Ubi Jalar Ungu (Ipomoea batatas L) sebagai Fotosensitiser pada Sel Surya Pewarna Tersensitisasi. Salatiga, Seminar Nasional 2nd Lontar Physics Forum.

Tiandho, Y., Dinata, I., Sunanda, W., Gusa, R. F., \& Novitasari, D. (2019). Solar Energy Potential in Bangka Belitung Islands, Indonesia. IOP Conference Series: Earth and Environmental Science, 257, 012022.

Tiandho, Y., Sunanda, W., Afriani, F., Indriawati, A., \& Handayani, T. P. (2018). Accurate Model for Temperature Dependence of Solar Cell Performance According to Phonon Energy. Latvian Journal of Physics and Technical Sciences, 55(5), 15-25.

van Helden, W., van Zolingen, R., \& Zondag, H. (2004). PV Thermal Systems: PV Panels Supplying Renewable Electricity and Heat. Progress in Photovoltaics: Research and Applications, 12(6), 415426.

Walujo, S., \& Harsanto, A. (2017). Proses Distilasi Etanol dengan Menggunakan Kolektor Surya Plat Datar. Jurnal Pilar Teknologi, 2(1), 59-64.

Weldekidan, H., Strezov, V., \& Town, G. (2018). Review of Solar Energy for Biofuel Extraction. Renewable and Sustainable Energy Reviews, 88, 184-192.

Widodo, D., \& Andrasto, T. (2010). Pemberdayaan Energi Matahari sebagai Energi Listrik Lampu Pengatur Lalu Lintas. Jurnal Teknik Elektro, 2(2), 148157.

Yazdanifard, F., \& Ameri, M. (2018). Exergetic Advancement of Photovoltaic/ Thermal Systems (PV/T): A Review. Renewable and Sustainable Energy Reviews, 97, 529-553. 